\title{
MENCIPTAKAN PEMBELAJARAN FUN LEARNING BASED ON SCIENTIFIC APPROACH DALAM PEMBENTUKAN KARAKTER PESERTA DIDIK PADA PEMBELAJARAN PAI
}

\author{
Leni Layyinah*
}

\author{
Sekolah Pascasarjana, Universitas Pendidikan Indonesia \\ *Email: el.layinah@gmail.com
}

\begin{abstract}
Nowadays, Indonesian education is posed with the increasing challenges of the third millennium. One of the infrastructures in Indonesia is school. A rigid school will not be a good learning place, because children only go to school without learning. In teaching and learning process, teachers should be aware that education is not merely about teaching. Instead, it is about how teachers should be able to create a fun learning atmosphere and implement the subject of Islamic Education by not only teaching religious knowledge but also directing students and forming their characters. The research took Equal Bright Primary School in Bandung as sample of an international-standard school promoting Multiple Intelligences. The analysis of the data on each aspect of instructional strategies reveals certain uniqueness in the teaching and learning process implemented in Equal Bright, which is full of fun and very interesting. The implementation of fun learning strategy through scientific approach plays a vital role in exploring student's potentials. The birth of this strategy gives a great expectation for the birth of the future generation with good quality and mentality to compete in the global arena. Equal Bright is an education institution implementing the method of multiple intelligences holistically, in which students are accommodated according to their learning and thinking styles. In implementing the fun learning strategies through scientific approach, the teaching and learning process can be more active, creative, effective, and fun.
\end{abstract}

Keywords: Character Formation, Fun Learning, Multiple Intelligences, Scientific. 


\section{PENDAHULUAN}

Dalam Undang-Undang No. 20 Pasal 40 Ayat 2 menjelaskan bahwa pendidik dan tenaga kependidikan berkewajiban menciptakan suasana pendidikan yang bermakna, menyenangkan, kreatif, dinamis dan dialogis. Mengacu pada Peraturan Pemerintah (PP) No. 19 Pasal 19 Ayat 1 berbunyi: "Proses pembelajaran pada satuan pendidikan diselenggarakan secara interaktif, inspiratif, menyenangkan, menantang, memotivasi peserta didik untuk berpartisipasi aktif, memberikan ruang gerak yang cukup bagi prakarsa, kreativitas dan kemandirian sesuai dengan bakat, minat dan perkembangan fisik, serta psikologi peserta didik". Rancangan pembelajaran yang inovatif tentu membutuhkan peran guru dalam menciptakan pola pembelajaran. Sebagaimana yang terjadi saat ini tantangan yang dihadapi dalam proses pembelajaran PAI adalah bagaimana mengimplementasikan PAI bukan hanya mengajarkan pengetahuan tentang agama saja melainkan bagaimana seorang guru mampu mengarahkan dan membentuk karakter peserta didik agar memiliki kualitas keimanan, ketakwaan dan akhlak mulia.

Dalam pelaksanaan PAI di sekolah yang selama ini terjadi lebih menekankan pada hafalan padahal Islam syarat dengan nilai-nilai yang harus dipraktekkan dalam kehidupan sehari-hari. Akibatnya, peserta didik kurang memahami kegunaan dan manfaat dari materi PAI yang menyebabkan tidak adanya motivasi bagi peserta didik untuk belajar materi PAI. Dalam merealisasikan pelaksanaan PAI guru dituntut untuk menguasai pengetahuan dan teknik mengajar yang baik agar mampu menciptakan suasana pembelajaran yang efektif dan efisien. Dunia pendidikan adalah dunia yang dinamis dan butuh update hal-hal yang baru secara terus menerus (Chatib, 2013, hal. 84). Maka dari itu lahirlah strategi pembelajaran fun learning dikembangkan oleh Bobby DePorter dengan memberikan sugesti positif.

Bobbi DePorter menyatakan bahwa strategi pembelajaran menyenangkan (Fun learning) adalah strategi yang digunakan untuk menciptakan lingkungan belajar yang efektif, menerapkan kurikulum, menyampaikan materi, memudahkan proses belajar yang mengakibatkan prestasi belajar peserta didik mengalami perbaikan (Darmasyah, 2011, hal. 45). Sebagaimana yang diungkapkan Djamarah (2010, hal. 377) bahwa pembelajaran menyenangkan merupakan pembelajaran yang didesain sedemikian rupa sehingga memberikan suasana penuh keceriaan, menyenangkan dan yang paling utama tidak membosankan. Dengan kata lain, pembelajaran yang menyenangkan adalah adanya pola hubungan yang baik antara guru dan peserta didik dalam proses pembelajaran. Keadaan aktif dan menyenangkan tidaklah cukup bila proses pembelajaran tidak efektif, yaitu tidak menghasilkan apa yang harus dikuasai peserta didik setelah proses pembelajaran berlangsung.

Menurut Fadillah (2014, hal. 176), Scientific approach adalah pendekatan pembelajaran yang dilakukan melalui proses mengamati (observing), menanya (questioning), mencoba (experimenting), menalar (associating), dan mengkomunikasikan (communication). Scientific approach dimaksudkan untuk memberikan pemahaman kepada peserta didik dalam mengenal dan memahami berbagi materi manggunakan pendekatan scientific. Pembelajaran diarahkan untuk mendorong peserta didik mencari tahu dari berbagai sumber pengamatan, bukan sekedar diberikan oleh guru. Metode scientific ini memiliki karakteristik "doing science".

Metode ini memudahkan guru atau pengembang kurikulum untuk memperbaiki proses pembelajaran, yaitu dengan memecah proses ke dalam langkah-langkah atau tahapan-tahapan secara terperinci yang memuat instruksi 
untuk peserta didik melaksanakan kegiatan pembelajaran. Menurut Maria Varelas and Michael Ford scientific approach dimaksudkan untuk memberikan pemahaman kepada peserta didik dalam mengenal, memahami berbagai materi menggunakan pendekatan ilmiah, bahwa informasi bisa berasal dari mana saja, kapan saja, tidak bergantung pada informasi searah dari guru (Mariana, 2014, hal. 32). Oleh karena itu, kondisi pembelajaran yang diharapkan tercipta diarahkan untuk mendorong peserta didik dalam mencari tahu dari berbagai sumber observasi, bukan diberi tahu.

Menurut Thomas Lickona orang yang berkarakter adalah sifat alami seseorang dalam merespon situasi secara bermoral, yang dimanifestasikan dalam tindakan nyata melalui tingkah laku yang baik, jujur, bertangung jawab, menghormati orang lain dan karakter mulia lainnya. Pengertian ini mirip dengan apa yang diungkapkan Aristoteles bahwa karakter erat kaitannya dengan habit atau kebiasaan yang terus-menerus dilakukan (Muslich, 2013, hal. 36). Peserta didik dalam pendidikan Islam adalah individu sedang tumbuh dan berkembang, baik secara fisik, psikologis, sosial dan religious dalam mengarungi kehidupan di dunia dan di akhirat kelak. Definisi tersebut memberi arti bahwa peserta didik merupakan individu yang belum dewasa, yang karenanya memerlukan orang lain untuk menjadikan dirinya dewasa. Anak adalah peserta didik dalam keluarga, murid adalah peserta didik di sekolah, anak-anak penduduk adalah peserta didik dalam masyarakat sekitarnya, dan umat beragama menjadi peserta didik ruhaniawan dalam suatu agama (Mujib, 2008, hal. 103).

Menurut Zakiyah Darajat, Pendidikan Agama Islam adalah suatu usaha untuk membina dan mengasuh peserta didik agar senantiasa dapat memahami ajaran Islam secara menyeluruh. Lalu menghayati tujuan, yang pada akhirnya dapat mengamalkan serta menjadikan Islam sebagai pandangan hidup (2000, hal. 86). Tujuan pendidikan Islam adalah penyempurnaan akhlak. Sebab misi Nabi dalam dakwahnya adalah memperbaiki akhlak umat manusia, sebagai mana sabdanya: "Innama buitstu li utammima makarim al-akhlak", bahwasanya aku diutus untuk menyempurnakan akhlak (Rahman, 2012, hal. 2058).

Teknik untuk memberikan sugesti positif seperti yang diungkapkan Riyanto (2010, hal. 184) seperti "mendudukkan peserta didik secara nyaman, memasang musik latar di dalam kelas, meningkatkan prestasi individu, menggunakan posterposter untuk memberikan kesan besar sambil menonjolkan informasi, dan menyediakan guru-guru yang terlatih baik dalam seni pengajaran sugesti". Dalam pembelajaran menyenangkan, pembelajaran harus berpusat pada murid (student centered learning). Model sekolah yang menyenangkan dengan pendekatan yang ramah anak merupakan model sekolah masa depan. Sekolah Multiple Intelligences adalah oase yang hadir di tengah keringnya dunia pendidikan.

Salah satu Sekolah Dasar (SD) yang berada di kota Bandung yang menerapkan sistem pendekatan Multiple Intelligences yaitu Sekolah Equal Bright. Sekolah Equal Bright adalah sebuah lembaga pendidikan yang menggunakan Kurikulum Nasional dan International Primary Curriculum (IPC), dengan metode belajar mengajar yang berdasarkan pendekatan dan implementasi Kecerdasan Majemuk (Multiple Intelligences/ MI) anak secara langsung dan konkrit. Dengan diterapkannya metode Kecerdasan Majemuk secara holistik di sekolah, anakanak diakomodasi sesuai dengan gaya belajar dan pola pikirnya. Hasil yang diharapkan adalah kemampuan anak memecahkan masalah, kemampuan beradaptasi dan keterampilan hidup apa yang dikuasainya.

Untuk itu dalam penelitian ini, bertujuan untuk mengetahui bagaimana penerapan yang dilakukan oleh guru PAI 
di sekolah dalam upaya menciptakan pembelajaran Fun Learning Based On Scientific Approach dalam pembentukan karakter peserta didik. Dalam penelitian ini peneliti akan menganalisis dan mendeskripsikan bagaimana guru tersebut mampu menciptakan pembelajaran Fun learning Based On Scientific Approach, sehingga mampu meningkatkan motivasi peserta didik untuk dapat berpartisipasi aktif dalam menciptakan kondisi belajar yang menyenangkan dan mudah dalam memahami materi pembelajaran PAI melalui Scientific Approach.

\section{METODE}

Penelitian ini menggunakan pendekatan kualitatif dengan metode deskriptif analisis. Dalam penelitian ini, peneliti menggunakan studi lapangan (field research), yaitu studi yang berdasarkan fakta yang terjadi pada objek penelitian. Meskipun studi lapangan, penelitian ini tetap melakukan kajian pustaka (library research) yang berfungsi sebagai sumber landasan teori. Pada penelitian ini, peneliti menggunakan teknik pengumpulan data dengan teknik observasi, wawancara mendalam, dan dokumentasi.

Dokumentasi dan pengumpulan data pendukung dalam penelitian ini peneliti gunakan untuk melengkapi penelitian dan untuk memaksimalkan hasil penelitian. Dalam penelitian kualitatif, pengumpulan data dilakukan pada natural setting (kondisi yang alamiah), sumber data primer, dan teknik pengumpulan data lebih banyak pada observasi, wawancara mendalam, dan dokumentasi (Sugiyono, 2012, hal. 224-225). Instrumen penelitian dalam penelitian ini diturunkan dari variabel penelitian dalam judul tesis ini. Yang selanjutnya diturunkan menjadi sub variabel yaitu cakupan lebih sempit dibandingkan variabel itu sendiri. Kemudian diturunkan menjadi dimensi dan indikator yang cakupannya lebih spesifik dan khusus. Selanjutnya barulah dijadikan sebagai kisi-kisi instrumen dalam penelitian ini.
Peneliti terjun sendiri ke lapangan, melakukan pengumpulan data, analisis, dan membuat kesimpulan. Dalam penelitian ini, uji keabsahan data dilakukan dengan triangulasi sumber dan teknik. Triangulasi sumber dilakukan dengan membandingkan data hasil observasi dengan data hasil wawancara, studi dokumentasi. Sedangkan triangulasi teknik merupakan pengecekan keabsahan data hasil penelitian dengan menggunakan beberapa teknik pengumpulan data yaitu observasi, wawancara, studi dokumentasi. Ketika hasil wawancara, observasi, studi dokumentasi sudah diketik rapih maka data diserahkan kepada pihak narasumber untuk dicek ulang validitas datanya.

\section{HASIL DAN PEMBAHASAN}

\section{Pendekatan, Metode, dan Teknik Pembelajaran}

Sebuah sistem proses pembelajaran yang dimulai dari awal pembelajaran sampai dengan akhir pembelajaran. Model pembelajaran di kelas Moslem Religion Equal Bright melingkupi:

\section{a. Pendekatan Pembelajaran}

Suatu sudut pandang guru terhadap proses pembelajaran. Proses tersebut mewadahi, menginspirasi, menguatkan, dan melatari metode pembelajaran. Pendekatan pembelajaran yang diterapkan di kelas Moslem Religion: student centered approach (pendekatan berpusat pada peserta didik) dan menerapkan pendekatan multiple intelligence dalam pembelajaran dan pendekatan scientific approach (pendekatan berbasis saintifik).

\section{b. Strategi Pembelajaran}

Dalam strategi pembelajaran, guru mengajar dan peserta didik belajar adalah dua proses yang berbeda. Artinya, ketika guru mengajar, belum tentu peserta didik belajar. Ketika peserta didik melakukan banyak aktivitas, itulah sebenarnya saat peserta didik belajar. Strategi Pembelajaran yang diterapkan di kelas Moslem Religion: fun learning 
(pembelajaran yang menyenangkan), integrated learning (pembelajaran yang mengintegrasikan materi pelajaran dalam satu pembahasan), learning by doing (proses membangun scientific skill).

\section{c. Metode Pembelajaran}

Dalam setiap pembelajaran metode merupakan komponen yang penting dalam pencapaian tujuan yang ingin ditetapkan, seorang guru harus terampil dalam menentukan metode yang tepat dengan pelajaran yang ingin disampaikan. Guru PAI menggunakan metode yang bervariasi agar pelajaran tidak membosankan dan bisa menarik perhatian peserta didik. Berdasarkan hasil wawancara dan observasi yang peneliti lakukan, guru PAI dalam penyampaian materi pembelajaran menggunakan metode presentasi, simulasi, demonstrasi, klasifikasi, eksperimendan keteladanan.

\section{d. Teknik Pembelajaran}

Teknik pembelajaran yang dilaksanakan pada proses pembelajaran PAI menerapkan teknik belajar yang menyenangkan disamping gurunya yang kreatif dan inovatif. Sehingga proses pembelajaran pun sangat menyenangkan. Dalam gaya pembelajaran yang diterapkan oleh guru PAI selain strategi fun learning guru pun selalu mendesain pembelajaran semenarik mungkin. Metode eksperimen melalui pendekatan saintifik. Karena guru PAI sangat menyukai dan memahami bidang sains sehingga dalam gaya mengajarnya pun punya kekhasan tersendiri keunikan yang dimiliki oleh guru PAI diterapkan dalam proses pembelajaran sesuai dengan kemampuan dan kepribadian dari guru tersebut.

Dalam proses pembelajaran guru PAI pun mempunyai kekhasan dalam menggunakan media pembelajaran yang diterapkan dalam pembelajaran PAI, karena media merupakan penyalur informasi belajar, media dapat mewakili apa yang kurang mampu guru ucapkan melalu kata-kata atau kalimat tertentu.
Media yang biasanya digunakan oleh guru PAI yaitu disesuaikan dengan materi yang akan diajarkan, misalkan materi pemilihan lingkungan dalam bergaul metode pembelajaran tema ini menggunkan metode eksperimen dengan media atau bahan-bahan yang digunakan diantaranya 3 gelas kosong, air, pewarna makanan, tisue, bunga putih. Materi rukun iman, Islam dan tugas malaikat media yang digunakan kerta A4, pulpen, double tip. Tentang materi kebaikan dan keburukan media yang digunakannya minuman, sedotan, dan gelas. Materi adab makan dan minum dalam Islam metode pembelajaran yang digunakan presentasi dengan mendatangkan ahli kesehatan dr. Kartika, beliau diundang sebagai narasumber dalam menyampaikan materi tentang pola makan dan minum yang baik dan benar menurut pandangan ilmu kesehatan dan guru PAI memberikan materi tentang adab makan dan minum dalam Islam.

\section{Menciptakan Pembelajaran Fun learning Based On Scientific Approach dalam Pembentukan Karakter Peserta Didik}

Bagi guru Equal Bright dalam menerapkan startegi belajar waktu guru menyampaikan presentasinya hanya $30 \%$, sedangkan $70 \%$ digunakan untuk peserta didik beraktivitas. Keberhasilan pembelajaran akan lebih cepat terwujud apabila proses transfer dilakukan dengan suasana yang menyenangkan.

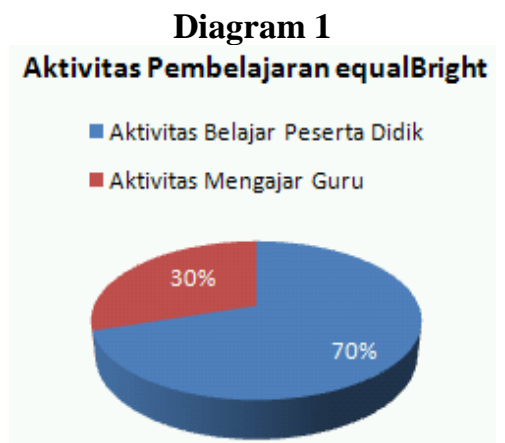

Berdasarkan observasi yang diperoleh peneliti, bahwa di Equal Bright strategi fun learning telah diterapkan secara efektif. Dalam proses pembelajaran 
di kelas Guru PAI Equal Bright menerapkan strategi Fun Learning diantaranya

\section{a. Suasana Pembelajaran yang Menyenangkan}

Suasana belajar mengajar yang tercipta di dalam kelas agar dapat membuat peserta didik melakukan pengalaman, interaksi, komunikasi, dan refleksi. Dalam menciptakan suasana yang mengembangkan inisiatif dan bertanggung jawab belajar peserta didik, maka guru harus selalu mengembangkan sikap dan perilaku diantaranya:

1) Terbuka dan mendengarkan pendapat peserta didik

2) Membiasakan peserta didik untuk saling mendengarkan saat berbicara

3) Menghargai perbedaan pendapat

4) Mentolelir perbuatan peserta didik yang salah dan mendorong untuk memperbaiki

5) Menumbuhkan rasa percaya diri dalam diri peserta didik

6) Memberi umpan balik terhadap hasil kerja peserta didik

7) Tidak pelit untuk memuji dan menghargai hasil karya peserta didik

8) Tidak menertawakan pendapat atau hasil karya peserta didik sekalipun kurang berkualitas

9) Mendorong peserta didik untuk tidak takut melakukan kesalahan dan berani menanggung resiko atas semua tindakannya.

Tabel 1

Kegiatan Pembelajaran PAI

\begin{tabular}{|c|c|c|}
\hline \multirow{2}{*}{ Komponen } & \multicolumn{2}{|c|}{ Kegiatan } \\
\hline & Peserta didik & Guru \\
\hline \multirow{3}{*}{ Pengalaman } & - Melakukan pengamatan & - Membuat kegiatan \\
\hline & - Melakukan percobaan & - Mengamati peserta didik bekerja \\
\hline & - Membaca & - Mengajukan pertanyaan \\
\hline \multirow{3}{*}{ Interaksi } & - Mengajukan pertanyaan & $\begin{array}{l}\text { Mendengarkan dan sesekali } \\
\text { mengajukan pertanyaan }\end{array}$ \\
\hline & $\begin{array}{l}\text { - Meminta pendapat orang } \\
\text { lain }\end{array}$ & $\begin{array}{l}\text { - Mendengarkan dan memberi } \\
\text { kesempatan kepada peserta didik } \\
\text { yang lain untuk menjawab }\end{array}$ \\
\hline & - Saling Bekerja sama & $\begin{array}{l}\text { - Berkeliling melihat keadaan } \\
\text { peserta didik sesekali duduk } \\
\text { bersama, dan berbicang } \\
\text { memberikan komentar pertanyan }\end{array}$ \\
\hline \multirow{5}{*}{ Komunikasi } & $\begin{array}{l}\text { - Memperhatikan dan } \\
\text { mengajukan pertanyaan }\end{array}$ & $\begin{array}{l}\text { - Mendemonstrasikan/ } \\
\text { mempertunjukkan }\end{array}$ \\
\hline & - Menceritakan & - Menjelaskan \\
\hline & $\begin{array}{l}\text { Mendengarkan, memberi } \\
\text { komentar atau pertanyaan }\end{array}$ & - Berbicara \\
\hline & $\begin{array}{l}\text { Melaporkan secara lisan } \\
\text { atau tertulis }\end{array}$ & - Bercerita \\
\hline & $\begin{array}{l}\text { - Mengemukakan pikiran } \\
\text { atau pendapat }\end{array}$ & - Memajang hasil karya \\
\hline Refleksi & $\begin{array}{l}\text { - Memikirkan kembali hasil } \\
\text { kerja }\end{array}$ & - Saling tukar pendapat \\
\hline
\end{tabular}

Dalam Fun Learning guru dan peserta didik ada dalam interaksi yang dinamis. Kalau keduanya pasif dan tidak kreatif, maka fun learning tidak dapat berjalan sesuai dengan koridornya. Berikut ini gambaran mengenai peran guru dan peserta didik dalam proses pembelajaran.

\section{Tabel 2}

Peran Guru dan Peserta Didik dalam Pembelajaran

\begin{tabular}{|c|c|}
\hline \multicolumn{2}{|c|}{ Strategi Fun Learning melalui Pendekatan Saintifik } \\
\hline Guru & $\begin{array}{l}\text { Peserta Didik } \\
\end{array}$ \\
\hline $\begin{array}{l}\text { Mengembangkan kegiatan } \\
\text { yang menarik dan beragam }\end{array}$ & - Membuat/ merancang \\
\hline - Membuat alat bantu & - Melakukan uji coba \\
\hline - Memanfaatkan lingkungan & $\begin{array}{l}\text { Kegiatan belajar menarik, } \\
\text { menantang }\end{array}$ \\
\hline $\begin{array}{l}\text { Mengelola kelas dan } \\
\text { sumber belajar }\end{array}$ & $\begin{array}{l}\text { Meningkatkan motivasi } \\
\text { belajar }\end{array}$ \\
\hline $\begin{array}{l}\text { Merencanakan proses dan } \\
\text { hasil belajar }\end{array}$ & $\begin{array}{l}\text { Kemampuan berfikir kritis } \\
\text { dalam memecahkan masalah }\end{array}$ \\
\hline $\begin{array}{l}\text { - Memberikan motivasi bagi } \\
\text { peserta didik }\end{array}$ & - berani mencoba \\
\hline $\begin{array}{l}\text { Tidak membuat peserta } \\
\text { didik takut }\end{array}$ & - Berani bertanya \\
\hline $\begin{array}{l}\text { Tidak membuat peserta } \\
\text { didik takut salah }\end{array}$ & $\begin{array}{l}\text { Berani memberikan } \\
\text { gagasan / pendapat }\end{array}$ \\
\hline $\begin{array}{l}\text { Tidak membuat peserta } \\
\text { didik ditertawakan }\end{array}$ & $\begin{array}{l}\text { - Berani mempertanyakan } \\
\text { gagasan orang lain }\end{array}$ \\
\hline
\end{tabular}

\section{b. MenciptakanPembelajaran yang Menyenangkan}

1) Menyapa Peserta Didik dengan Ramah dan Semangat

Menciptakan awal yang berkesan adalah penting karena akan mempengaruhi proses selanjutnya. Jika awalnya baik, menarik, dan memikat, maka proses pembelajaran akanlebih hidup dan menggairahkan. Salah satu hal yang harus dikedepankan dalam menciptakan suasana belajar yang menyenangkan adalah menyertakan partisipasi peserta didik di dalam kelas. Selain untuk membangun komunikasi dengan peserta didik, guru PAI juga dapat mengetahui apa yang menjadi kebutuhan bagi peserta didik. Jika situasi ini tak terbangun, bisa jadi peserta didik akan merasa canggung berbicara dengan guru dan komunikasi tidak akan berjalan baik. Akibatnya, guru juga akan mengalami kesulitan untuk mengetahui apa yang menjadi keinginan peserta didik.

Oleh karena itu guru PAI selalu mengawali kegiatan pembelajaran dengan memberikan sapaan hangat kepada peserta didik, misalnya "anak-anak senang bertemu kalian hari ini, kalian adalah 
anak-anak yang hebat". Karena sapaan hangat dan raut wajah cerah memantulkan energi positif yang dapat mempegaruhi semangat para peserta didik. Dapat dibayangkan jika seorang guru ketika memulai pembelajaran dengan raut muka ruwet, tidak senyum, penampilan kusut, tentu saja suasana kelas menjadi menegangkan dan menakutkan.

\section{2) Menciptakan Lingkungan Kelas Yang Menarik \\ Ruang kelas pun didesain berbeda} dengan tata ruang kelas konvensional. Dalam suatu kelas disediakan learning centers sebagai sarana eksplorasi dan riset serta diskusi yang diharapkan mampu membangkitkan gairah belajar anak, terutama untuk mengembangkan pribadi masing masing baik secara individual dan secara social dengan sesamanya. Terdapat pajangan gambar-gambar dan hasil kerja peserta didik dan pernak pernik hiasan dinding yang beraneka ragam bentuk sehingga membuat peserta didik nyaman berada dikelas. Atmosfer kelas benarbenar sangat bersahabat dengan kondisi peserta didik. Sarana dan fasilitas yang ada di sekolah Equal Bright sangat menujang dalam proses pembelajaran dan membuat suasana begitu sangat nyaman.

\section{3) Memotivasi Peserta Didik}

Adanya dorongan dalam diri individu untuk belajar bukan hanya tumbuh dari dirinya secara langsung, tetapi bisa saja karena rangsangan dari luar, misalnya berupa stimulus model pembelajaran yang menarik memungkinkan respon yang baik dari diri peserta didik yang akan belajar. Respon yang baik tersebut, akan berubah menjadi sebuah motivasi yang tumbuh dalam dirinya, sehingga ia merasa terdorong untuk mengikuti proses pembelajaran dengan penuh perhatian dan antusias.

Apabila dalam diri peserta didik telah tumbuh respon, hingga termotivasi untuk belajar, maka tujuan belajar akan lebih mudah dicapai. Peserta didik yang antusias dalam proses pembelajaran memiliki kecenderungan berhasil lebih besar dibanding mereka yang mengikuti proses dengan terpaksa atau asal-asalan. Kebanyakan guru mengajar hanya untuk mengejar target tanpa memperdulikan pemahaman peserta didik. Padahal belajar adalah suatu bentuk aktivitas manusia yang memerlukan adanya motivasi untuk mencapai tujuan. Guru PAI selalu berusaha memberikan motivasi dalam rangka meningkatkan minat dan dorongan bagi setiap peserta didiknya, ia tak jemu untuk memotivasi para peserta didiknya untuk selalu bersemangat dalam belajar, meningkatkan kemampuan yang dimiliki setiap peserta didik dan membangun karakter yang baik bagi peserta didik.

\section{4) Menggunakan Metode Yang Variatif} Variasi dalam gaya mengajar guru PAI didalam kelas menerapkan dengan berbagai cara seperti halnya mengatur variasi suara, rendah, tinggi, besar, kecil dalam rangka memfokuskan peserta didik agar selalu memusatkan perhatiannya dalam belajar. Guru pun selalu mengatur variasi gerakan badan dengan cara menggunakan boneka tangan berkomunikasi atau mengadakan role playing hal ini dilakukan agar peserta didik merasa senang dalam belajar dan juga menerapkan gerak musik dengan memberi rangsangan alunan nada musik yang akan merangsang anak rileks, tenang dan nyaman dalam mengikuti proses pembelajaran. Dalam hal mengubah posisi cara mengajar di depan kelas guru PAI tidak ada batasan dalam mengatur posisi mengajar karena pola belajar yang diterapkan didalam kelas tidak seperti kelas pada umumnya dimana guru duduk di depan dan peserta didik dibelakang proses pembelajaran yang diterapkan di Equal Bright beraneka ragam cara dan bentuk, posisi belajar pun berubah-ubah kadang berbentuk lingkaran, saling berhadapan, dalam hal pengaturan posisi belajar tidak ada batasan ruang gerak bagi peserta didik. 
Penggunaan media sebagai sumber belajar yang diterapkan guru PAI pada proses pembelajaran fun learning sangat bervariasi. Guru selalu menggunakan media yang menarik perhatian peserta didik agar peserta didik merasa senang dalam mengikuti setiap proses dari pembelajaran PAI dengan cara menggunakan laboratorium sains, seni lukis, membuat kerajinan dari lilin, penjelajah memecahkan kode-kode, mendaur ulang sampah, dan kampanye go green.

Variasi dalam kegiatan pembelajaran yang dilakukan oleh guru PAI sangat beragam diantaranya cara penggunaan metode pembelajaran yang menarik menerapkan strategi fun learning melalui pendekatan saintifik dengan penggunaan variasi metode, peserta didik tidak akan merasa bosan dan jenuh ketika belajar. Adanya integrated learning proses pembelajaran yang mengintegrasikan materi pelajaran dalam satu pembahasan dengan pembahasan yang lain. Mengintegrasikan agama dengan sains dengan cara percobaan dengan pendekatan saintifik yang bersifat ilmiah learning by doing proses untuk membangun scientific skill. Selain itu guru PAI pun selalu menerapkan keteladan dalam membangun karakter peserta didik.

\section{KESIMPULAN}

Equal Bright menerapkan sistem pendekatan student centered approach peserta didik dituntut untuk lebih aktif dalam belajar dan dalam proses pembelajaran PAI diterapkan juga scientifik approach. PAI Equal Bright menerapkan strategi pembelajaran fun learning. Selanjutnya strategi berdasarkan integrated learning pembelajaran yang mengintegrasikan materi pelajaran dalam satu pembahasan dan learning by doing proses membangun scientific skill pembelajaran. Guru PAI menggunakan metode yang bervariasi menggunakan metode presentasi, simulasi, demonstrasi, klasifikasi, eksperimen dan keteladanan. Teknik pembelajaran yang dilaksanakan pada proses pembelajaran PAI menerapkan teknik belajar yang menyenangkan disamping guru yang kreatif dan inovatif. Dalam gaya pembelajaran yang diterapkan oleh guru PAI mendesain pembelajaran eksperimen melalui pendekatan saintifik.

Bagi guru Equal Bright dalam menerapkan startegi belajar waktu guru menyampaikan presentasinya hanya $30 \%$ sedangkan $70 \%$ digunakan untuk peserta didik beraktivitas. Dalam Strategi pembelajaran fun learning hampir tidak mempunyai kelemahan, hal tersebut dikarenakan strategi ini menitikberatkan pada pengembangan potensi masingmasing peserta didik dan hal tersebut merupakan belajar berdasarkan fitrahnya. Hanya satu kelemahan dalam startegi ini, yakni tertuju pada keprofesionalan seorang guru. Seberapa besar guru memiliki kemampuan atau kompetensi untuk mengajar. Hal tersebut yang mempengaruhi seberapa besar dia mampu mengaplikasikan dengan baik strategi fun learning ini ke dalam kelas.

Strategi pendekatan saintifik pada mata pelajaran PAI dalam mengintegrasikan sains dengan agama, sehingga mampu untuk meningkatkan pencapaian Ilmu-Amaliah dan AmalIlmiah serta berupaya menjadikan pembelajaran PAI kepada tujuan yang utama, yaitu untuk menjadikan peserta didik yang berakhlak mulia dalam kehidupan sehari-harinya serta akan melahirkan manusia-manusia unggul yang partisipatif, berkarkter Islami, berakhlak mulia. 


\section{REFERENSI}

Chatib, M. (2013). Sekolahnya Manusia Sekolah Berbasis Multiple Intelligences di Indonesia. Bandung: Kaifa.

Daradjat, Z. (2000). Ilmu Pendidikan Islam. Jakarta: Bumi Aksara.

Darmasyah. (2011). Strategi Pembelajaran Menyenangkan Dengan Humor. Jakarta: Bumi Aksara.

Djamarah, S. B. (2010). Guru \& Anak Didik dalam Interaksi Edukatif. Jakarta: Rineka Cipta.

Fadillah, M. (2014). Implementasi Kurikulum $2013 \quad$ Dalam Pembelajaran SD/MI SMP/MTS \& SMA/MA. Yogjakarta: Ar-Ruzz Media.

Gunawan, A. W. (2012). Genius Learning Strategy . Jakarta : Gramedia Pustaka Utama .

Mariana, M. A. (2014). Profil Proses Pembelajaran Dan Proses Penilaian Jenjang Pendidikan Dasar Dikota Denpasar Provinsi Bali . Jurnal .

Moleong, L. J. (2011). Metodologi Penelitian Kualitatif . Bandung : Remaja Rosdakarya.
Mujib, A. (2008). Ilmu Pendidikan Islam . Jakarta: Fajar Interpratama Offset.

Mulyasa, E. (2007). Menjadi Guru Profesional Menciptakan Pembelajaran Kreatif dan Menyenangkan. Bandung: Rosdakarya.

Muslich, M. (2013). Pendidikan Karakter Menjawab Tantangan Krisis Multidimensional. Jakarta: Bumi Aksara.

Mustafa, Z. (2009). Mengurai Variabel Hingga Instrumentasi . Yogjakarta: Graha Ilmu.

Rahman, A. (2012). Pendidikan Agama Islam dan Pendidikan Islam Tinjauan Estimologi dan Isi Materi. Eksis, 8 (1), 2001-2181.

Riyanto, Y. (2010). Paradigma Baru Pembelajaran. Jakarta: Kencana Prenada Media.

Sugiyono. (2012). Metode Penelitian Kuantitatif, Kualitatif, dan $R \& D$. Bandung: Alfabeta.

Sukmadinata, N. S. (2006). Metode Penelitian Pendidikan. Bandung: Remaja Rosda karya. 